\title{
The Prevalence of Parasitic Contamination of Fresh Vegetables in Tehran, Iran
}

\author{
Tahran/Iran'da Taze Sebzelerin Parizitik Kirliliğinin Yaygınlı̆̆ Hakkında \\ Araştırma
}

\author{
(1) Mahdi Isazadeh ${ }^{1}$, (1) Iraj Mirzaii-Dizgah², (1) Minoo Shaddel ${ }^{3}$, (1) Mohamad Mohsen Homayouni ${ }^{3}$ \\ ${ }^{1}$ Aja University of Medical Sciences Faculty of Medicine, Student Research Committee, Tehran, Iran \\ ${ }^{2}$ Aja University of Medical Sciences Faculty of Medicine, Department of Physiology, Tehran, Iran \\ ${ }^{3}$ Aja University of Medical Sciences Faculty of Medicine, Department of Parasitology, Tehran, Iran
}

Cite this article as: Isazadeh M, Mirzaii-Dizgah I, Shaddel M, Homayouni MM. The Prevalence of Parasitic Contamination of Fresh Vegetables in Tehran, Iran. Turkiye Parazitol Derg 2020;44(3):143-8.

\begin{abstract}
Objective: Parasitic diseases have created numerous health and economic problems in developing and developed countries. One of the most prevalent ways of transmitting diseases is by consuming raw vegetables that are contaminated with parasites. With respect to the importance of healthy vegetable consumption, an awareness of vegetable status helps prevent infection. Therefore, the present study was conducted to determine the level of parasitic contamination of vegetables consumed in Tehran.

Methods: This descriptive and cross-sectional study was conducted on vegetable samples spread in Tehran from October 2017 to September 2018. The samples included 240 vegetables selected from 10 types of vegetable including leek, basil, mint, spring onion, radish, parsley, lettuce, cress, tarragon and coriander. Each sample was examined after passing through washing and centrifuging. Parasitic agents such as unicellular, egg and larva of the worms were studied. The data were analysed using SPSS software.

Conclusion: Parasitic infection was observed in 62 samples (25.8\%). The highest and lowest rates of contamination were observed in coriander and lettuce, respectively. Rhabditoid larva (12.5\%; 15 cases) and Physaloptera egg (1.6\%; 2 cases) were the most and least observed parasites, respectively. Other parasites such as Entamoeba, Giardia, Blastocystis, Hymenolepis, Ascaris and the egg and larva of hookworms were also observed. Despite the relative improvement of social, agricultural, economic and health conditions in Tehran, the prevalence of parasitic infections still persists. Factors such as developing modern waste collection methods, improving urban sewage systems, preventing domestic animal traffic on pastures and promoting the knowledge of different classes of people could reduce the prevalence of these types of diseases.
\end{abstract}

Keywords: Parasitic infection, Consumed vegetables, Tehran

ÖZ

Amaç: Parazitik hastalıklar, gelişmiş ve gelişmekte olan ülkelerde sağlık ekonomisi alanında pek çok sorun yaratmıştır. Parazitlerle kontamine olmuş çiğ sebzeleri tüketmek, hastalıkların bulaşında en yaygın yollarından biri olarak kabul edilir. Sağlıklı sebze tüketiminin ilgili farkındalık, enfeksiyonu önlemede önemlidir. Bu sebeple, bu çalışmada Tahran'da tüketilen sebzelerin parazitik kontaminasyon düzeyininin belirlenmesi amaçlanmıştır.

Yöntemler: Bu tanımlayıcı ve kesitsel çalışma, Ekim 2017-Eylül 2018 tarihleri arasında Tahran'da bulunan sebze örnekleri üzerinde gerçekleştirilmiştir. Örnekler, pırasa, fesleğen, nane, yeşil soğan, turp, maydanoz, marul, tere, tarhun otu ve kişniş dahil olmak üzere 10 çeşit sebzeden seçilen toplam 240 sebzeyi içeriyordu. Her numune yıkama ve santrifüjden geçtikten sonra incelendi. Solucanların tek hücreli, yumurta ve larvaları gibi paraziter ajanlar incelendi. Elde edilen verileri analiz etmek için SPSS yazılımı kullanıldı.

Sonuç: Bulgulara dayanarak, örneklerin 62'sinde $(\% 25,8)$ parazitik enfeksiyon gözlenmiştir. Kişniş ve marul sırasıyla en yüksek ve en düşük kontaminasyon oranına sahipti. Sonuçlar, en fazla ve en az görülen parazitlerin Rabditoid larvası \%12,5 (15 olgu) ve Physaloptera yumurtası \%1,6 (2 olgu) olduğunu göstermiştir. Entamoeba, Giardia, Blastocystis, Hymenolepis, Ascaris ve kancalı kurtların yumurta ve larvaları gibi diğer parazitler de gözlenmiştir. Tahran'daki sosyal, tarımsal, ekonomik ve sağlık koşullarının göreceli iyileşmesine rağmen, paraziter enfeksiyonlar halen belli bir prevalansta gözlenmektedir. Modern atık toplama yöntemlerinin kullanılması, kentsel kanalizasyon sistemlerinin iyileştirilmesi, merada evcil hayvan trafiğinin önlenmesi ve göreceli olarak farklı toplumsal sınıfların bilgi sahibi olmalarının teşvik edilmesi gibi faktörler bu tür hastalıkların prevalansını azaltabilir. Anahtar Kelimeler: Parazitik enfeksiyon, tüketilen sebzeler, Tahran 


\section{INTRODUCTION}

Healthy life has been an important objective for humans all the time. Economic and social status of human, level of health care, level of education, method of farm irrigation, vegetable consumption, and utilization of human fertilizers in farms are the effective elements in the infectious of human parasites (1-3). In addition, the contaminated vegetables can spread infectious and parasitic diseases to human (4). Consuming the raw vegetables, along with food as Iranian customs, can infect the consumer with parasites, in addition to supplying a wide range of vitamins for body.

Parasitic factors can contaminate the vegetables in several ways: Using human fertilizers in agriculture, which can be infected by Giardia, Amoeba, Cryptosporidium, Isospora, Toxoplasma, Hymenolepis, Taenia, Hydatid cyst, Trichuris, Trichostrongylus, Ascaris, Hookworms, and Strongiloides.

1. Utilizing animal fertilizers infected with common parasites between human and domesticated animals $(4,5)$.

2. Use sewage for irrigating the farms.

3. Contaminating vegetables during production, collection, transportation, and preparation for sale.

4. Traffic of infected animals such as dogs, cats, and other wild carnivores in the farms (Toxoplasma, Hydatid cyst).

More than 40 million people are infected with parasitic infections, and more than $10 \%$ of the population is at risk for parasitic infections in the world. Due to the high prevalence of parasitic infections, identifying the infectious resources, and preventing the methods of their transmission and development are the specific priorities of health (6).

The present study aimed to determine the condition and type of parasitic contamination of edible vegetables in Tehran in order to help determine the contamination level of each vegetable and improve the level of public health.

\section{MATERIALS AND METHODS}

In the present descriptive study, 240 vegetable samples were selected from autumn 2017 to summer 2018. The samples included leek, basil, mint, spring onion, radish, parsley, lettuce, cress, tarragon, and coriander, which are used raw. The samples were randomly selected from wet markets and costermongers in Tehran.

Each sample was collected up to $200 \mathrm{~g}$ in sterile nylon bags and transferred to the parasitology laboratory of Aja University of Medical Science for examination. Then, they were tested by sediment concentration method, recommended by Food and Drug Administration.

To this aim, the samples were washed in 1 liter buckets of water containing detergent solution ( $1 \%$ sodium dodecyl sulfate, $0.1 \%$ tween 80) for 10 minute and then the water was collected in propylene's beakers and next, centrifuged in tubes at $3000 \mathrm{rpm}$ for 10 minutes. The upper layer of the tubes was discharged. Then, the sediments were recombined. Six slides were taken from each sample, and Lugol's iodine solution was added to three of them. The samples were examined by $\times 10$ and $\times 40$ magnification of the optical microscope, and the average of parasite was recorded. In addition, they were carefully observed to identify the egg and larva of the worms, as well as the cyst and trophozoite of the unicellulars (7).

This descriptive and cross-sectional study was approved by the Ethics Committee Aja University Faculty of Medicine, Tehran, Iran, (decision no: IR.AJAUMS.REC.1300.050), and was performed according to the tenets of the Declaration of Helsinki.

\section{Statistical Analysis}

The data were analyzed using SPSS software (ver. 21) and descriptive statistics (mean and percentage).

\section{RESULTS}

The results indicated that 62 samples $(25.8 \%)$ had at least one type of contamination (Table 1 ).

Parasitic agents of larval Filariform with 9.1\% (11 cases), Rhabditoid larva with $12.5 \%$ (15 cases), Hookworm egg with $10 \%$ (12 cases), Ascaris egg with 10.8\% (13 cases), Hymenolepis egg with $7.4 \%$ (9 cases), Physaloptera egg with $1.6 \%$ (2 cases), Giardia cyst with $7.4 \%$ (9 cases), Blastocystis cyst with $8.2 \%$ (10 cases), and Entamoeba cyst with $4.1 \%$ (5 cases) were observed (Table 2). The highest and lowest frequency of parasites related to Rhabditoid larva (12.5\%), and Physaloptera egg (1.6\%), respectively. The

Table 1. Vegetable samples positive for parasitic structures with mono and multiple contaminants sold from Tehran, Iran, 2017

\begin{tabular}{|c|c|c|c|c|c|}
\hline \multirow{2}{*}{ Vegetable type } & \multirow{2}{*}{ Number } & \multirow{2}{*}{ Positive items (\%) } & \multicolumn{3}{|c|}{ Number of parasite in one sample } \\
\hline & & & One-parasitic & Two-parasitic & Three-parasitic \\
\hline Basil & 24 & $11(45.8 \%)$ & $9(37.5 \%)$ & $1(4.2 \%)$ & $1(4.2 \%)$ \\
\hline Cress & 24 & $2(8.3 \%)$ & $1(4.2 \%)$ & - & $1(4.2 \%)$ \\
\hline Parsley & 24 & $3(12.5 \%)$ & $2(8.3 \%)$ & $1(4.2 \%)$ & - \\
\hline Coriander & 24 & $1(4.2 \%)$ & $1(4.2 \%)$ & - & - \\
\hline Tarragon & 24 & $3(12.5 \%)$ & $3(12.5 \%)$ & - & - \\
\hline Spring onion & 24 & $6(25 \%)$ & $3(12.5 \%)$ & $2(8.3 \%)$ & $1(4.2 \%)$ \\
\hline Radish & 24 & $8(33.3 \%)$ & $4(16.6 \%)$ & $2(8.3 \%)$ & $2(8.3 \%)$ \\
\hline Lettuce & 24 & $14(58.3 \%)$ & $10(41.6 \%)$ & $3(12.5 \%)$ & $1(4.2 \%)$ \\
\hline Mint & 24 & $7(29.2 \%)$ & $5(20.8 \%)$ & $2(8.3 \%)$ & - \\
\hline Leek & 24 & 7 (29.2\%) & $5(20.8 \%)$ & $1(4.2 \%)$ & $1(4.2 \%)$ \\
\hline Total & 240 & $62(25.8 \%)$ & $43(17.9 \%)$ & $12(5 \%)$ & 7 (2.9\%) \\
\hline
\end{tabular}




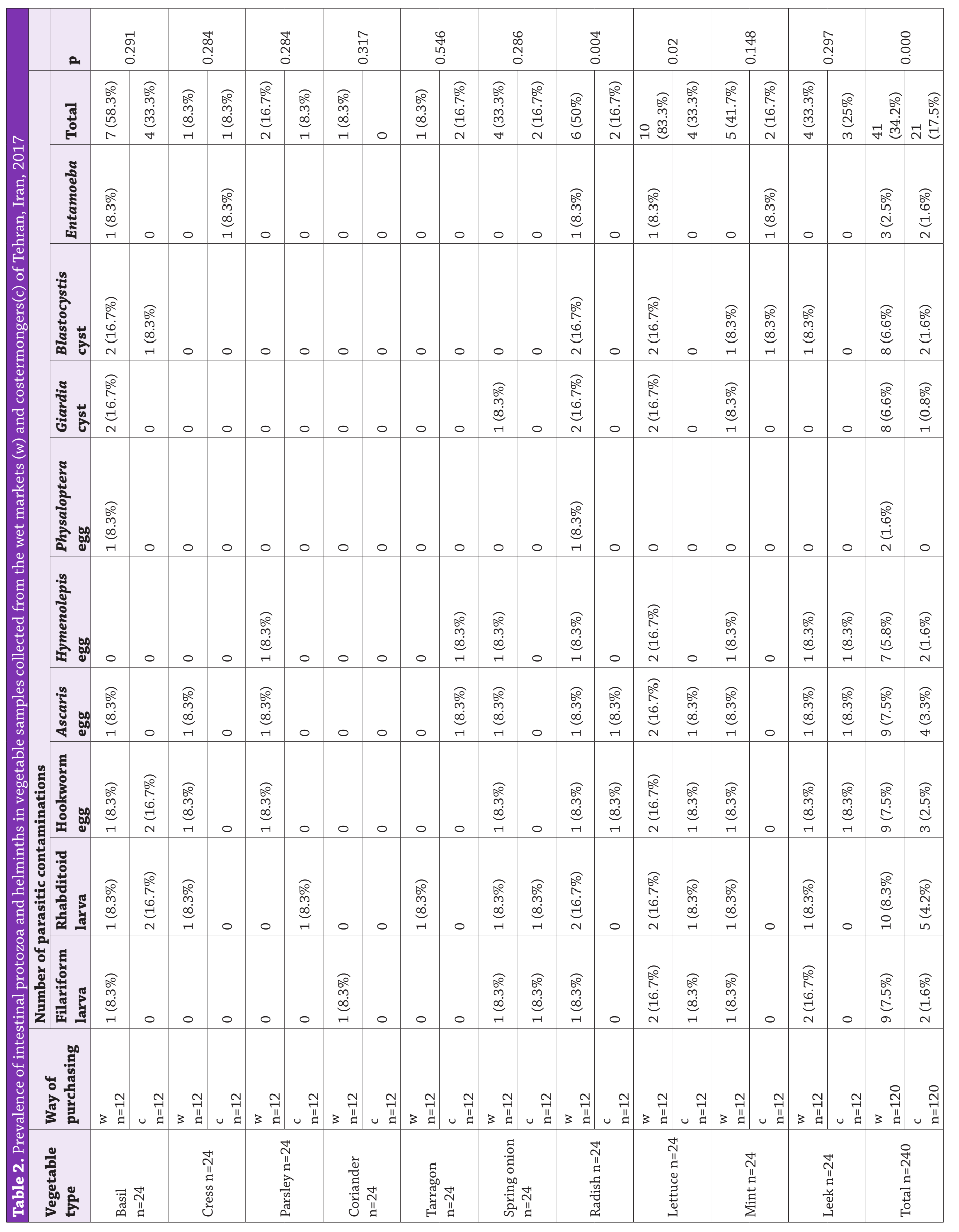


highest contamination observed in lettuce (14 cases, 58.3\%) and the lowest in coriander (one case, 4.2\%) (Table 3).

\section{DISCUSSION}

In the present study, which was conducted in fresh vegetable samples in Tehran, the results were analyzed after collecting the samples, transferring them to the laboratory, and finally performing microscopic observations. As evident, Rhabditoid larva with 15 cases and Physaloptera egg with 2 cases were the most and the least parasitic factors, respectively (Table 2).

The total amount of parasitic contamination of the vegetables in the study was $25.8 \%$. The rate was reported 29.6, 13.76, 65, 53.62, and $38 \%$ in Kerman, Isfahan, Tehran, and Shahroud, respectively (1,8-10).

Parasitic infections of consumed vegetables in Bengal, Morocco, and Nigeria were $44.2 \%, 50 \%$, and $3.5 \%$ respectively (11-13). Parasitic contamination of vegetable consumption in Turkey and Norway was reported significant $(14,15)$. In Nigeria and Turkey, the amount was reported $36 \%$ and $5.9 \%$, respectively $(16,17)$. The studies in Japan and Saudi Arabia indicated spring onion as the most contaminated type of vegetable (18). Along with the results of the present study, lettuce was the most contaminated vegetable in Khartoum (19).

In the present study, worm infections were more than protozoa
(Table 2,3). In the studies conducted in Isfahan, Yazd, and Bushehr, vegetables were contaminated by metazoa more than protozoa, which is consistent with results of the present study $(9,20,21)$.

About $12.5 \%$ of the infected contaminations were related to Rhabditoid larvae. The existence of larvae of the third stage (Filariform) with the second larvae indicates the presence of infectious larvae among humans and animals although the larvae of the nematodes of the soil were observed in this study, but were detected with infectious larvae due to lack of lamina in the second stage of larvae.

Although most of the larvaelive vegetative and free, contaminating the vegetables with mentioned larvae is likely to infect humans with Strongyloides stercoralis and other pathogenic nematodes. Therefore, the present findings should be taken important. In addition, Rhabditoid contamination has been reported in the studies conducted in Yazd and Bushehr (20,21).

The metazoan contaminations related to worm eggs in $29.8 \%$ cases, which are acceptable due to the use of human fertilizers in planting and animal traffic in the mentioned areas. The contamination of Hymenolepis egg was $7.4 \%$, which was similar to those of other regions of Iran (20).

Unicellular contaminations (Table 1) accounted for $19.8 \%$ of parasitic infections, which was higher than that of Qazvin and Kermanshah (22,23). Similar to Qazvin contamination, Entamoeba

Table 3. Contamination items of intestinal protozoa and helminths in each purchase

\begin{tabular}{|c|c|c|c|c|c|c|c|c|c|c|c|}
\hline \multirow{2}{*}{\multicolumn{2}{|c|}{ Purchase order }} & \multicolumn{10}{|c|}{ Number of parasitic } \\
\hline & & \multirow{2}{*}{$\begin{array}{l}\text { Basil } \\
4 \\
\end{array}$} & \multirow{2}{*}{\begin{tabular}{|l|} 
Cress \\
0 \\
\end{tabular}} & \multirow{2}{*}{\begin{tabular}{|l} 
Parsley \\
1 \\
\end{tabular}} & \multirow{2}{*}{$\begin{array}{l}\text { Coriander } \\
0 \\
\end{array}$} & \multirow{2}{*}{$\begin{array}{l}\text { Tarragon } \\
0 \\
\end{array}$} & \multirow{2}{*}{\begin{tabular}{|l|} 
Spring onion \\
2 \\
\end{tabular}} & \multirow{2}{*}{$\begin{array}{l}\text { Radish } \\
1 \\
\end{array}$} & \multirow{2}{*}{$\begin{array}{l}\text { Lettuce } \\
1 \\
\end{array}$} & \multirow{2}{*}{$\begin{array}{l}\text { Mint } \\
0 \\
\end{array}$} & \multirow{2}{*}{$\begin{array}{l}\text { Leek } \\
2 \\
\end{array}$} \\
\hline 1 & $\mathrm{w}$ & & & & & & & & & & \\
\hline 1 & c & 1 & 0 & 0 & 0 & 0 & 0 & 0 & 0 & 0 & 0 \\
\hline \multirow{2}{*}{2} & $\mathrm{w}$ & 0 & 0 & 0 & 0 & 1 & 1 & 1 & 4 & 0 & 0 \\
\hline & c & 0 & 0 & 0 & 0 & 0 & 0 & 0 & 0 & 0 & 1 \\
\hline \multirow{2}{*}{3} & $\mathrm{w}$ & 1 & 0 & 0 & 0 & 0 & 1 & 2 & 2 & 0 & 0 \\
\hline & c & 0 & 0 & 0 & 0 & 0 & 0 & 0 & 2 & 0 & 0 \\
\hline \multirow{2}{*}{4} & $\mathrm{w}$ & 0 & 1 & 1 & 0 & 0 & 0 & 1 & 1 & 1 & 0 \\
\hline & c & 0 & 0 & 0 & 0 & 0 & 1 & 0 & 1 & 0 & 0 \\
\hline \multirow{2}{*}{5} & $\mathrm{w}$ & 0 & 0 & 0 & 0 & 0 & 0 & 0 & 0 & 2 & 0 \\
\hline & c & 0 & 0 & 0 & 0 & 0 & 0 & 0 & 1 & 1 & 0 \\
\hline \multirow{2}{*}{6} & $\mathrm{w}$ & 0 & 0 & 0 & 0 & 0 & 0 & 1 & 0 & 0 & 0 \\
\hline & c & 1 & 0 & 0 & 0 & 0 & 0 & 0 & 0 & 1 & 0 \\
\hline \multirow{2}{*}{7} & $\mathrm{w}$ & 0 & 1 & 0 & 1 & 0 & 0 & 1 & 1 & 0 & 0 \\
\hline & c & 0 & 0 & 0 & 0 & 0 & 0 & 0 & 0 & 0 & 1 \\
\hline \multirow{2}{*}{8} & $\mathrm{w}$ & 2 & 0 & 0 & 0 & 0 & 0 & 0 & 0 & 0 & 2 \\
\hline & c & 0 & 1 & 1 & 0 & 0 & 0 & 0 & 0 & 0 & 0 \\
\hline \multirow{2}{*}{9} & $\mathrm{w}$ & 1 & 1 & 1 & 0 & 0 & 0 & 2 & 1 & 2 & 1 \\
\hline & c & 0 & 0 & 0 & 0 & 0 & 1 & 1 & 0 & 0 & 0 \\
\hline \multirow{2}{*}{10} & $\mathrm{w}$ & 0 & 0 & 0 & 0 & 0 & 2 & 2 & 3 & 1 & 1 \\
\hline & c & 0 & 0 & 0 & 0 & 1 & 0 & 0 & 0 & 0 & 0 \\
\hline \multirow{2}{*}{11} & $\mathrm{w}$ & 1 & 0 & 0 & 0 & 0 & 0 & 1 & 1 & 0 & 0 \\
\hline & c & 1 & 0 & 0 & 0 & 0 & 0 & 0 & 0 & 0 & 1 \\
\hline \multirow{2}{*}{12} & $\mathrm{w}$ & 1 & 0 & 0 & 0 & 0 & 0 & 0 & 1 & 1 & 1 \\
\hline & c & 1 & 0 & 0 & 0 & 1 & 0 & 0 & 0 & 0 & 0 \\
\hline
\end{tabular}


covered $4.1 \%$ of the infections (23). Separating this parasite from the vegetable may not be important for pathogenicity, but given the fact that the contamination indicates the infection of human excrement, it can be of great importance in terms of health.

Giardia was observed in $7.4 \%$ cases. Proper sanitation of the vegetables is necessary because of the pathogenicity of this parasite and its transmission to humans. The results were consistent with that of other studies in Golestan province (6.8\%), and Ardabil city (7\%), but inconsistent with that of Shahrood city $(2,10,24)$.

However, the present results were different with those of other studies conducted in Syria (25), Pakistan (26), Egypt (27), Ethiopia (28), Nigeria (6,29), and Vietnam (30). These differences could arise from geographical location and climate, the number of samples, the methods used to identify the parasite, the type of irrigation, the use of human or animal fertilizer, the amount of parasitic infection in the human population, and the methods of vegetable transportation.

In the present study, 10 types of vegetables were tested, and the most contaminated one was lettuce, (Table 3 ) which may be related to its wrinkles which require more careful rinse, which is in line with many exhaustive studies $(19,25-27,31,32)$.

Coriander was reported as the lowest infectious, which was different from other investigations (10). It seems that the contamination level of vegetables with different parasites according to their type necessitates more research.

In the present study, the rate of infection with Ascaris egg was $10.8 \%$, which is different from the contamination of other countries such as Libya $68 \%$, Saudi Arabia 16\%, Turkey 14\%, and South Korea (18,33-35).

No significant difference was observed in the contamination rates of leek, basil, mint, spring onion, parsley, cress, tarragon, and coriander in different shopping centers. However, a significant difference was observed between the wet markets and its bunch in radish $(\mathrm{p}=0.004)$ and Lettuce $(\mathrm{p}=0.02)$. It is worth noting that the vegetables purchased from wet market (with root) significantly carried more parasitic contaminations than vegetables purchased of costermongers (with no root) $(\mathrm{p}=0.000)$ (Table 2 and 3 ).

Controlling the animal traffic within the farm and fencing the fields can play an important role in reducing parasitic eggs in vegetables. If the fertilizer is accumulated with no parasites (prolonged accumulation such as compost), the construction of lavatories in gardens can be effective in reducing parasitic infections, and ultimately reducing transmitted diseases (8).

\section{CONCLUSION}

Although the rate of contamination among human parasites has been reported lower than that of other provinces such as Khuzestan, Lorestan, Hamedan, and Isfahan due to the utilization of animal and chemical fertilizers in agriculture; according to the high level of contamination with infectious stages of animal nematodes which can sometimes appear as zoonosis, it is recommended that the vegetables be washed with respect to health care considerations. Informing the public by press and mass media can be effective in reducing the contamination in the region.

\section{* Ethics}

Ethics Committee Approval: This descriptive and crosssectional study was approved by the Ethics Committee AJA university, Faculty of Medicine, tehran, Iran, (decision no: IR.AJAUMS.REC.1300.O50), and was performed according to the tenets of the Declaration of Helsinki.

Informed Consent: We have any patient in this study.

Peer-review: Internally peer-reviewed.

\section{* Authorship Contributions}

Concept: M.I., I.M.D., M.S., M.M.H., Design: M.I., M.S., M.M.H., Data Collection or Processing: M.I., M.S., M.M.H., Analysis or Interpretation: M.M.H., Literature Search: M.I., M.S., M.M.H., Writing: M.I., M.S., M.M.H.

Conflict of Interest: The authors confirm that this article content has no conflict of interest.

Financial Disclosure: The authors declared that this study received no financial support.

\section{REFERENCES}

1. Gharavi M, Jahani M, Rokni M. Parasitic contamination of vegetables from farms and markets in Tehran. Iranian J Publ Health 2002; 31: 83-6.

2. Daryani A, Ettehad G, Sharif M, Ghorbani L, Ziaei H. Prevalence of intestinal parasites in vegetables consumed in Ardabil, Iran. Food control 2008; 19: 790-4.

3. Siyadatpanah A, Tabatabaei F, Zeydi AE, Spotin A, Fallah-Omrani V, Assadi M, et al. Parasitic contamination of raw vegetables in Amol, North of Iran. Archives of Clinical Infectious Diseases 2013; 8.

4. Shaddel M, Sharifi I, Karvar M, Keyhani A, Baziar Z. Cryotherapy of cutaneous leishmaniasis caused by Leishmania major in BALB/c mice: A comparative experimental study. J Vector Borne Dis 2018; 55: 42-6.

5. Parvin Z, Iraj MD, Minoo S, Fatemeh K. Effects of Toxoplasma gondii infection on anxiety, depression and ghrelin level in male rats. J Parasit Dis 2016; 40: 688-93.

6. Idahosa OT. Parasitic contamination of fresh vegetables sold in jos markets. Global Journal of Medical Research 2011; 11: 20-5.

7. Bier JW. Isolation of parasites on fruits and vegetables. Southeast Asian $j$ trop med public health 1991; (Suppl 22): 144-5.

8. Malakootian M, Hoseini M. Parasitic contamination of consuming vegetables in Kerman city Iran. Hormozgan Medical Journal 2009; 13: 55-62.

9. Izadi S, Abedi S, Ahmadian S, Mahmoodi M. Study of the current parasitic contamination of the edible vegetables in Isfahan in order to identify preventive measures. Scientific Journal of Kurdistan University of Medical Sciences 2006; 11: 51-8.

10. Nazemi S, Raei M, Amiri M, Chaman R. Parasitic contamination of raw vegetables in Shahroud, Semnan. Zahedan J Med Sci 2012; 14: 84-6.

11. Gupta N, Khan D, Santra S. Prevalence of intestinal helminth eggs on vegetables grown in wastewater-irrigated areas of Titagarh, West Bengal, India. Food control 2009; 20: 942-5.

12. Hajjami K, Ennaji M, Fouad S, Oubrim N, Cohen N. Wastewater reuse for irrigation in Morocco: Helminth eggs contamination's level of irrigated crops and sanitary risk (a case study of Settat and Soualem regions). J Bacteriol Parasitol 2013; 4: 1-5.

13. Adamu NB, Adamu JY, Mohammed D. Prevalence of helminth parasites found on vegetables sold in Maiduguri, Northeastern Nigeria. Food control 2012; 25: 23-6.

14. Turgay $\mathrm{O}$, Şener $\mathrm{H}$. The contamination of various fruit and vegetable with Enterobius vermicularis, Ascaris eggs, Entamoeba histolyca cysts and Giardia cysts. Food control 2005; 16: 557-60. 
15. Robertson L, Gjerde B. Occurrence of parasites on fruits and vegetables in Norway. J Food Prot 2001; 64: 1793-8.

16. Kozan E, Gonenc B, Sarimehmetoglu O, Aycicek H. Prevalence of helminth eggs on raw vegetables used for salads. Food Control 2005; 16: 239-42.

17. Damen J, Banwat E, Egah D, Allanana J. Parasitic contamination of vegetables in Jos, Nigeria. Ann Afr Med 2007; 6: 115-8.

18. Al-Binali AM, Bello CS, El-Shewy K, Abdulla SE. The prevalence of parasites in commonly used leafy vegetables in South Western, Saudi Arabia. Saudi Med J 2006; 27: 613-6.

19. Mohamed MA, Siddig EE, Elaagip AH, Edris AMM, Nasr AA. Parasitic contamination of fresh vegetables sold at central markets in Khartoum state, Sudan. Ann Clin Microbiol Antimicrob 2016; 15: 17.

20. Dehgani Frirozabadi A, Azizi M, Anvari M. A study of the contaminated vegetables in distribution centers of Yazd city. Toloo-EBehdasht J Health School 2004; 2: 5-11.

21. Sahebani N, Foladvand M, Dalimi A. Intestinal parasites contamination of vegetables in Bushehr port. Iranian South Medical Journal 1999; 1: 59-63.

22. Hamzavi Y, editor Contamination of edible vegetables with huma parasitic eggs in Kermanshah. 2nd Natianal congress of parasitic diseases; 1997.

23. Shahnazi M, Sharifi M, Kalantari Z, Heidari MA, Agamirkarimi N. The study of consumed vegetable parasitic infections in Qazvin. J Qazvin U Med Sci 2009; 12: 83.

24. Rahimi-Esboei B, Pagheh A, Fakhar M, Pagheh S, Dadimoghadam Y. Parasitic contamination of consumed vegetables in Golestan province, 2012. Medical Laboratory Journal 2014; 8: 82-9.

25. Alhabbal AT. The prevalence of parasitic contamination on common cold vegetables in Alqalamoun Region. Int J Pharm Sci Rev Res 2015; 30: 94-7.

26. Maqbool A, Khan UJ, Yasmin G, Sultana R. Parasitic contamination of vegetables eaten raw in Lahore. Pakistan Journal of Zoology 2014; 46: 1303-9.
27. Eraky MA, Rashed SM, Nasr ME-S, El-Hamshary AMS, Salah El-Ghannam A. Parasitic contamination of commonly consumed fresh leafy vegetables in Benha, Egypt. Journal of parasitology research 2014; 2014.

28. Benti G, Gemechu F. Parasitic contamination on vegetables irrigated with Awash river in selected farms, eastern Showa, Ethiopia. J Parasitol Vector Biol 2014; 6: 103-9.

29. Alade G, Alade T, Adewuyi I. Prevalence of intestinal parasites in vegetables sold in Ilorin, Nigeria. American-Eurasian J Agric \& Environ Sc 2013; 13: 1275-82.

30. Uga S, Hoa N, Noda S, Moji K, Cong L, Aoki Y, et al. Parasite egg contamination of vegetables from a suburban market in Hanoi, Vietnam. Nepal Med Coll J 2009; 11: 75-8.

31. Sunil B, Thomas DR, Latha C, Shameem H. Assessment of parasitic contamination of raw vegetables in Mannuthy, Kerala state, India. Veterinary World 2014; 7: 253-6.

32. Olyaei A, Hajivandi L. Parasitological contamination of markets and farms in vegetables consumed in southern Iran. Global Veterinaria 2013; 10: 327-31.

33. Abougrain AK, Nahaisi MH, Madi NS, Saied MM, Ghenghesh KS. Parasitological contamination in salad vegetables in Tripoli-Libya. Food control 2010; 21: 760-2.

34. Ulukanligil M, Seyrek A, Aslan G, Ozbilge H, Atay S. Environmental pollution with soil-transmitted helminths in Sanliurfa, Turkey. Memorias do Instituto Oswaldo Cruz 2001; 96: 903-9.

35. Choi DW, Ock MS, Suh JW. Recent demonstration of helminth eggs and larvae from vegetable cultivating soil. Kisaengchunghak Chapchi 1982; 20: 83-92 